\title{
The Propagation of Guavas from Stem Cuttings
}

\author{
W. Pennock and G. Maldonado
}

\section{INTRODUCTION AND OBJECTIVES}

During the past few years excellent clonal varieties of guavas have been selected in different parts of the world. We are aware that very good selections have been made in Florida, Hawaii, and Israel. Probably others have been made elsewhere. In Puerto Rico we have over a hundred very promising selections, the performance and desirable qualities of which are still being subjected to further comparison and study.

With the advent of highly desirable clonal varieties asexual propagation of guavas has become a matter of great importance for the development of this promising crop. Asexual reproduction is now performed by marcotting Ruehle $(1)^{2}$, by grafting Dedolph and Bowers (2), by the use of root cuttings Davila (3), and by the use of stem cuttings which were not altogether satisfactory, Jolicoeur (4). All of these methods are still used to some extent, suggesting that no one method has proven markedly superior to the others.

In our trials with these different methods we were impressed by the potentialities of propagation from stem cuttings. Despite low initial rooting obtained with stem cuttings we soon became convinced that much better rooting was possible, and that, once achieved, this would constitute a cheap, rapid, method lending itself to large-scale operations and yielding homogeneous plants that come into production quite rapidly. Our principal objective in these studies, therefore, has been to improve the rooting of stem cuttings.

This is the first of two projected publications dealing with guava propagation. We report herein on some of the experimental work dealing with guava rooting response and complement this with additional details recommended for use in routine propagation. The second publication will deal primarily with anthracnose disease and the means of preventing its damage to cuttings under mist propagation.

\section{METHODS AND MATERIALS}

We have worked primarily with young stem cuttings in which the leaves are left attached and which are placed for rooting in propagating beds provided with alternating mist controlled by timeclocks and a solenoid

${ }^{1}$ Horticulturist and Research Assistant, respectively, Department of Agronomy and Horticulture, Agricultural Experiment Station, University of Puerto Rico, Río Piedras, P.R.

${ }^{2}$ Italic numbers in parentheses refer to Iuterature Cited, 289. 
valve. Misting was set to take place during 10 seconds of every minute during daylight hours. Figure 1 shows such cuttings placed in a rooting bed under mist. The rooting medium was usually coarse sand and very fine gravel, but "Coco-peat" Vermiculite, "Mexifern", fir bark, and "Perlite" were also tried. The propagating beds were partly shaded by saran cloth rated at 50-percent shade, but actually providing considerably less. Such partial shading, though possibly slightly less desirable than full sunlight for rooting some species, is nevertheless a marked safety factor in case of electric power failure which shuts off the water.

The leaves were usually removed from the lower third of the stem of the

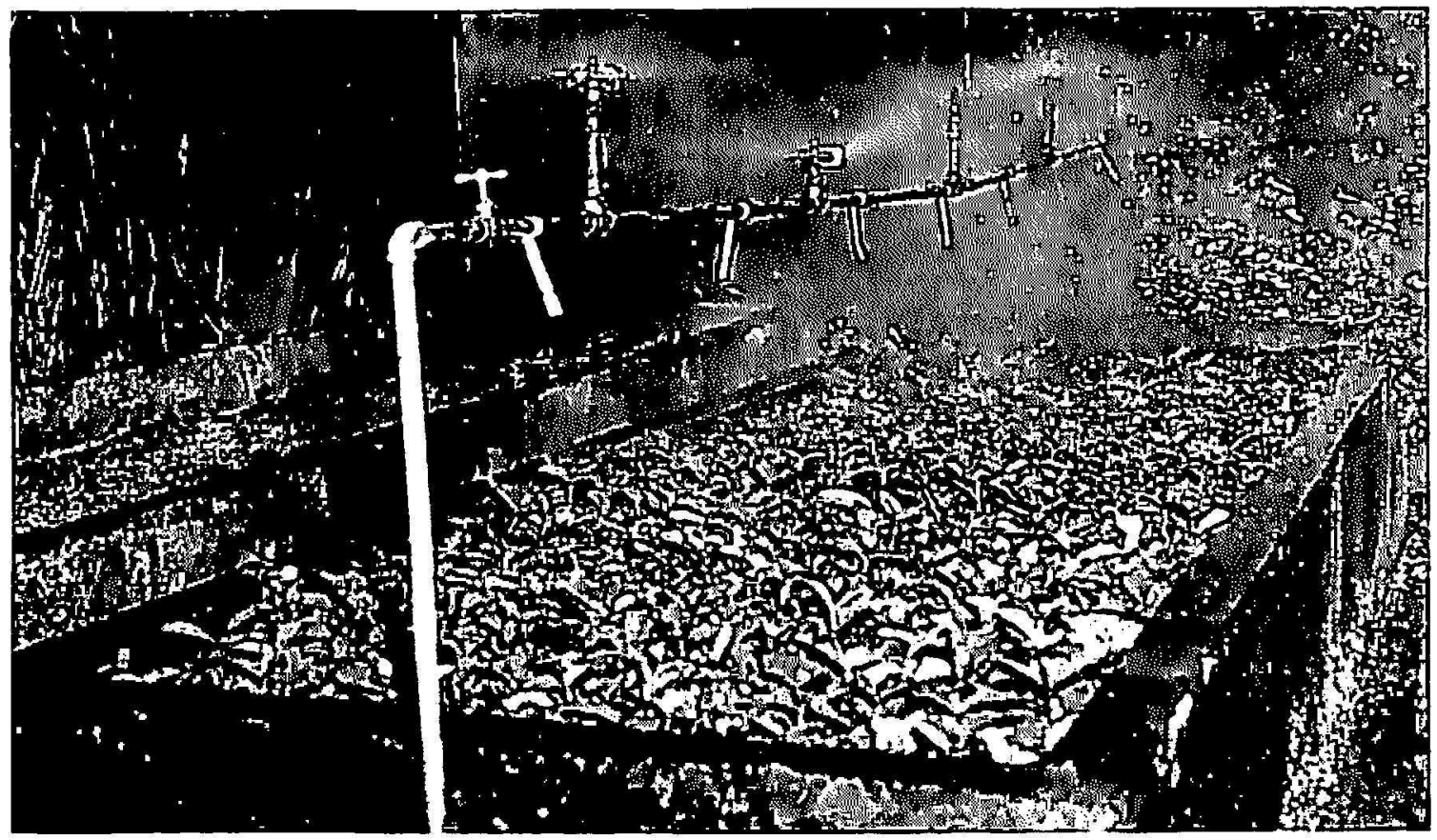

Fici, 1.-Ciuava cuttings rooting under mist propagation.

cuttings and their bases were immersed overnite to a depth of $3 / 4$ inch in the different solutions. For convenience in treatment the cuttings were rolled up in a "jelly-roll"-type bundle containing $2 ;$ cuttings with their butts trimmed evenly to insure an even depth of immesion.

\section{EXPLORA'TORY OBSERVATIONS}

Our most important improvement in technique consisted of stimulating the production of suitable young sprouts by severe pruning of the parent tree. All foliage was removed by means of a buckhorn-type pruning in which the overall height was limited to 6 to 10 feet, depending on age, and all the remaining branches were cut off at $1 / 2$-inch diameter, but conserving wherever possible a 6-to-12 inch spur from the nearest fork. Under our conditions whitewashing the stump was not necessary, since no sunburn- 
ing whatever was noted in any of the many trees which were pruned in this way at different seasons and in different localities.

Figure 2 shows a 4-year-old guava tree pruned in this manner 5 weeks after pruning. The first cutting of side-sprouts for rooting can be done

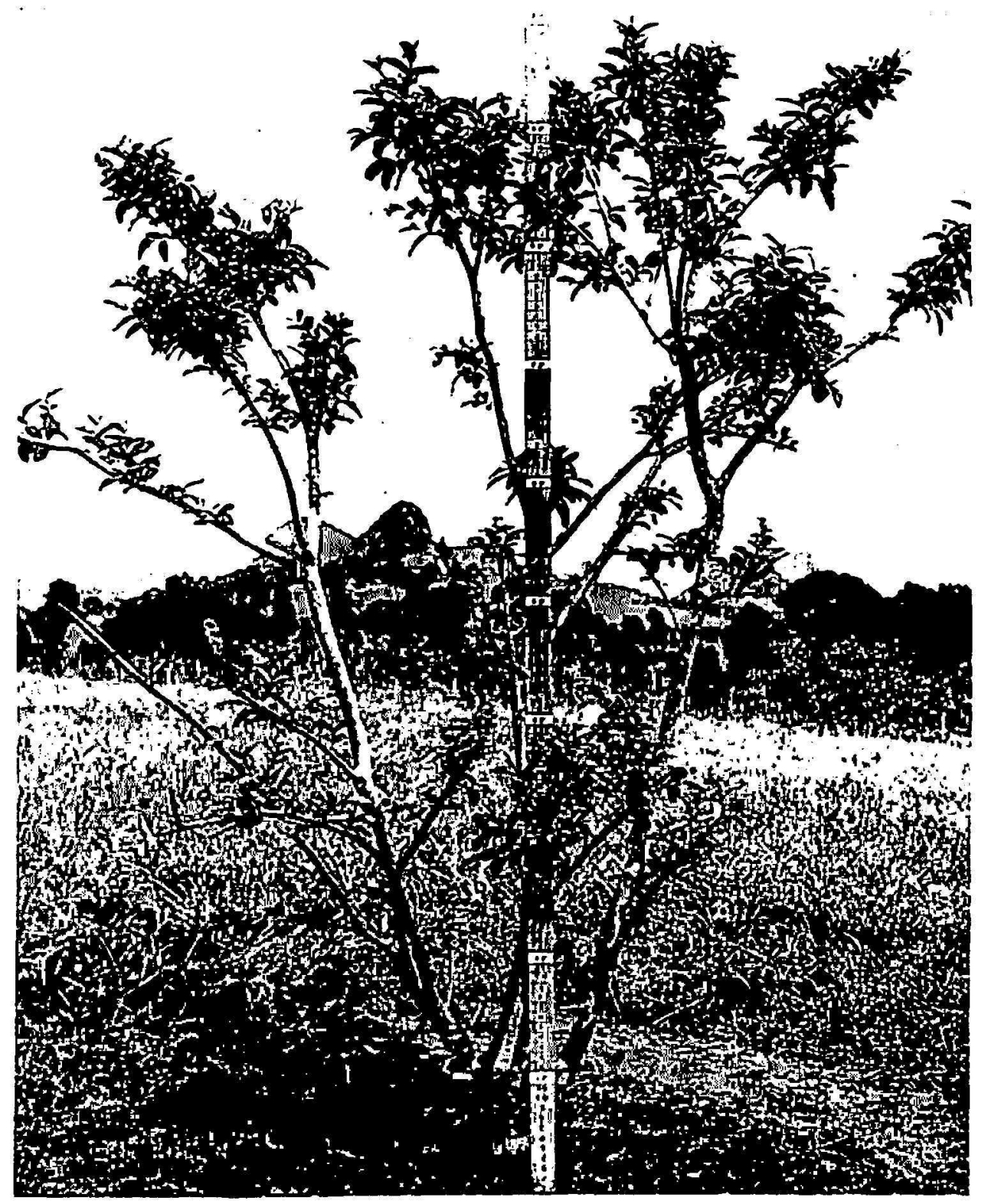

Firi. 2.--A 4-year-old guava tree pruned back to induce the formation of sidesprouts suitable for rooting. Pruning was earried out 5 weeks before this pieture was taken.

about 6 weeks after pruning when many of the largest sprouts will have 3 to 6 pairs of leaves. $A$ second, a third, and usually additional lots of cuttings may be taken at biweekly intervals thereafter, but in the third cut, sufficient sprouts well located on the branches should be conserved so that the tree may continue to grow and attain a desirable shape. 
Cuttings derived from such induced side-sprouts proved to be much more suitable for rooting than any of the other types of stem cuttings of all kinds which were tried. Repeated trials also showed that there is no advantage to be gained by taking cuttings with a "heel" of bark from the parent branch. In fact, removal of the heel greatly delayed the formation of secondary sprouts from the parent tree. which may also be used for propagation. In our experience 2- to 3 -year-old guava trees yield from 500 to 1,000 cuttings per tree within the first 3 months following pruning.

In our early experiments in which several thousand cuttings were used, we also learned that the use of strong concentrations of phytohormones were desirable, and that the cuttings being rooted under mist are quite vulnerable to anthracnose disease. Successful rooting in these early experiments was on the order of 20 percent or less.

\section{EXPERIMENTAL RESULTS}

On January 31, 1962, an experiment was set out with cuttings taken from two parent trees which were pruned on December 7, 1961. Table 1 shows the results obtained with cuttings subjected to four different treatments and placed in each of five different rooting media for a period of 26 days. The treatments consisted of immersing overnight the basal ends of the cuttings to a depth of $3 / 4$ inch in different solutions. As may be seen in table 1 , there was but little variation in the rooting which occurred in the different media, but there were big differences between treatments.

A chi-square test showed that there were no significant differences in the extent of rooting which occurred in the different media, but that highly significant differences did occur between treatments. The cuttings treated with indolebutyric acid (I.B.A.) plus sugar gave a highly significant increase in rooting when compared to all of the other treatments. The cuttings treated with indolebutyric acid alone also gave a highly significant increase in rooting when compared to those treated with either honey or sugar. The statistical analyses were performed by our Statistical Department.

The remaining cuttings were replanted in the same rooting media and were again examined on March 12, 40 days after the original planting. At this time the few remaining unrooted cuttings were invariably affected with anthracnose and were, therefore, discarded. In table 2 are shown the number of cuttings which rooted during the entire period of 40 days (including earlier rooting at the end of 26 days already shown in table 1.).

\section{DISCUSSION}

It may be noted in table 2 that most of the remaining cuttings eventually rooted in all treatments, but that the general trends observed in the initial data remained the same, yet with smaller differences between treatments. 
TABLE 1.-Number of guava cultings planted and the corresponding number which had rooted 26 days after planting in different media 1

\begin{tabular}{|c|c|c|c|c|c|c|c|c|c|c|c|c|c|}
\hline \multirow{4}{*}{ Solutions used in treatment } & \multicolumn{10}{|c|}{ Cuttings planted and rooted under rooting media indicated } & \multirow{2}{*}{\multicolumn{3}{|c|}{ Totals }} \\
\hline & \multicolumn{2}{|c|}{ Coco-peat } & \multicolumn{2}{|c|}{ Firbark } & \multicolumn{2}{|c|}{ Vermiculite } & \multicolumn{2}{|c|}{ Perlite } & \multicolumn{2}{|c|}{ Mexifern } & & & \\
\hline & \multirow{2}{*}{$-\frac{\text { Planted }}{\text { Number }}$} & \multirow{2}{*}{ Rooted } & \multirow{2}{*}{ Planted } & \multirow{2}{*}{$\mid \frac{\text { Rooted }}{\text { Number }}$} & \multirow{2}{*}{ Planted } & \multirow{2}{*}{$\mid \frac{\text { Rooted }}{N u m b e r}$} & \multirow{2}{*}{$\frac{\text { Planted }}{\text { Number }}$} & \multirow{2}{*}{$\mid \frac{\text { Rooted }}{\text { Number }}$} & \multirow{2}{*}{ Planted } & \multirow{2}{*}{$\frac{\text { Rooted }}{\text { Number }}$} & \multirow{2}{*}{$\frac{\text { Planted }}{\text { Number }}$} & \multicolumn{2}{|c|}{ Rooted } \\
\hline & & & & & & & & & & & & Number & Percent \\
\hline Honey & 21 & 3 & 20 & 4 & 22 & 2 & 21 & 3 & 20 & 7 & 104 & 19 & 18.27 \\
\hline Sugar, 2 percent & 20 & 4 & 20 & 3 & 19 & 7 & 21 & $\mathbf{3}$ & 20 & 3 & 100 & 20 & 20 \\
\hline Sugar, 2 percent + I.B.A. ${ }^{2} 200$ p.p.m. & 20 & 16 & 20 & 19 & 20 & 19 & 21 & 20 & 20 & 14 & 101 & 88 & 87.13 \\
\hline Totals planted & 82 & & 81 & & 82 & & 82 & & 81 & & 408 & & \\
\hline Totals rooted & & 37 & & 43 & & 46 & & 40 & & 35 & & 201 & \\
\hline Percentage of totals rooted & & 45 & & 53 & & 56 & & 49 & & 43 & & & 49.38 \\
\hline
\end{tabular}

1 The cuttings had been treated by overnight immersion of their basal ends in the different solutions indicated. The percentage of cuttings which rooted in each media and in each treatment total are also shown.

2 I.B.A. = indolebutyric acid. 
It may be concluded then that the different rooting media used in the experiment had little if any effect on the rooting of cuttings. Since the media chosen varied greatly in their physical properties, it may also be inferred that there are doubtless many suitable rooting media with little to choose between them, except possibly availability and convenience in planting. In consequence, we have elected to use and to recommend for rooting either sharp sand or a mixture of sand and Perlite. Both of these are easy to plant and easy to sterilize with methyl bromide.

The treatment with indolebutyric acid plus sugar undoubtedly was the best, but that with indolebutyric alone was almost as good. The results indicate not only that both of these treatments increased rooting, but that

TABLE 2.-Number of guava cuttings which had rooled 40 days after planting in each of the different medial

\begin{tabular}{|c|c|c|c|c|c|c|c|c|}
\hline \multirow{3}{*}{$\begin{array}{l}\text { Solutions used in } \\
\text { treatment }\end{array}$} & \multicolumn{5}{|c|}{ Cuttings rooted under rooting media indicated } & \multicolumn{3}{|c|}{ Totals } \\
\hline & $\begin{array}{l}\text { Coco- } \\
\text { peat }\end{array}$ & Fir bark & $\begin{array}{l}\text { Vermic- } \\
\text { ulite }\end{array}$ & Perlite & Mexifern & Planted & & bted \\
\hline & Number & Number & Number & Number & Number & Number & Number & Percent \\
\hline Honey, 2 percent & 13 & 14 & 14 & 14 & 15 & 104 & 70 & 67.3 \\
\hline I.B.A., ${ }^{2} 200$ p.p.m. & 18 & 18 & 20 & 16 & 18 & 103 & 90 & 88.2 \\
\hline Sugar, 2 percent & 12 & 15 & 13 & 16 & 17 & 100 & 73 & 73.0 \\
\hline $\begin{array}{l}\text { Sugar, } 2 \text { percent }+ \\
\text { I.B.A. } 200 \text { p.p.m. }\end{array}$ & 18 & 20 & 20 & 20 & 17 & 101 & 95 & 94.1 \\
\hline Total & 61 & 67 & 67 & 60 & (67 & 408 & 328 & 80.4 \\
\hline
\end{tabular}

1 The totals corresponding to cuttings treated, cuttings which rooted per treatment, and percentage of cuttings rooted per treatment are also shown.

${ }^{2}$ I.B.A. = indulebutyric acid.

they also reduced the time required to obtain satisfactory results. This is of great importance in avoiding disease. Moreover, cuttings so treated produced numerous vigorous roots which insured their rapid development into strong plants ready to be set out in the field. ligure 3 shows cuttings which had been treated with indolebutyric acid and were removed from the rooting bed 4 weeks after planting. Figure 4 shows young plants derived from similar cuttings planted in black polyethylene bags. large, vigorous trees such as these are the normal end-result 6 to 8 months after the cuttings are first taken for propagation by this method. Such trees generally give a small crop of fruit within a year.

\section{anthracnose diseasl and SUggested PRECAUTIONS}

In this experiment the losses from disease were very slight and occurred almost exclusively after the 26-day period. If such results could be obtained 
consistently, the method could be put into large-scale commercial operation immediately, without the need of further refinement or additional precautions. Unfortunately, however, cuttings rooted by this method are highly susceptible to anthracnose caused by Glomerella cingulaia, which also causes the mumification of guava fruits. The anthracnose of cuttings spreads with surprising rapidity under mist propagation.

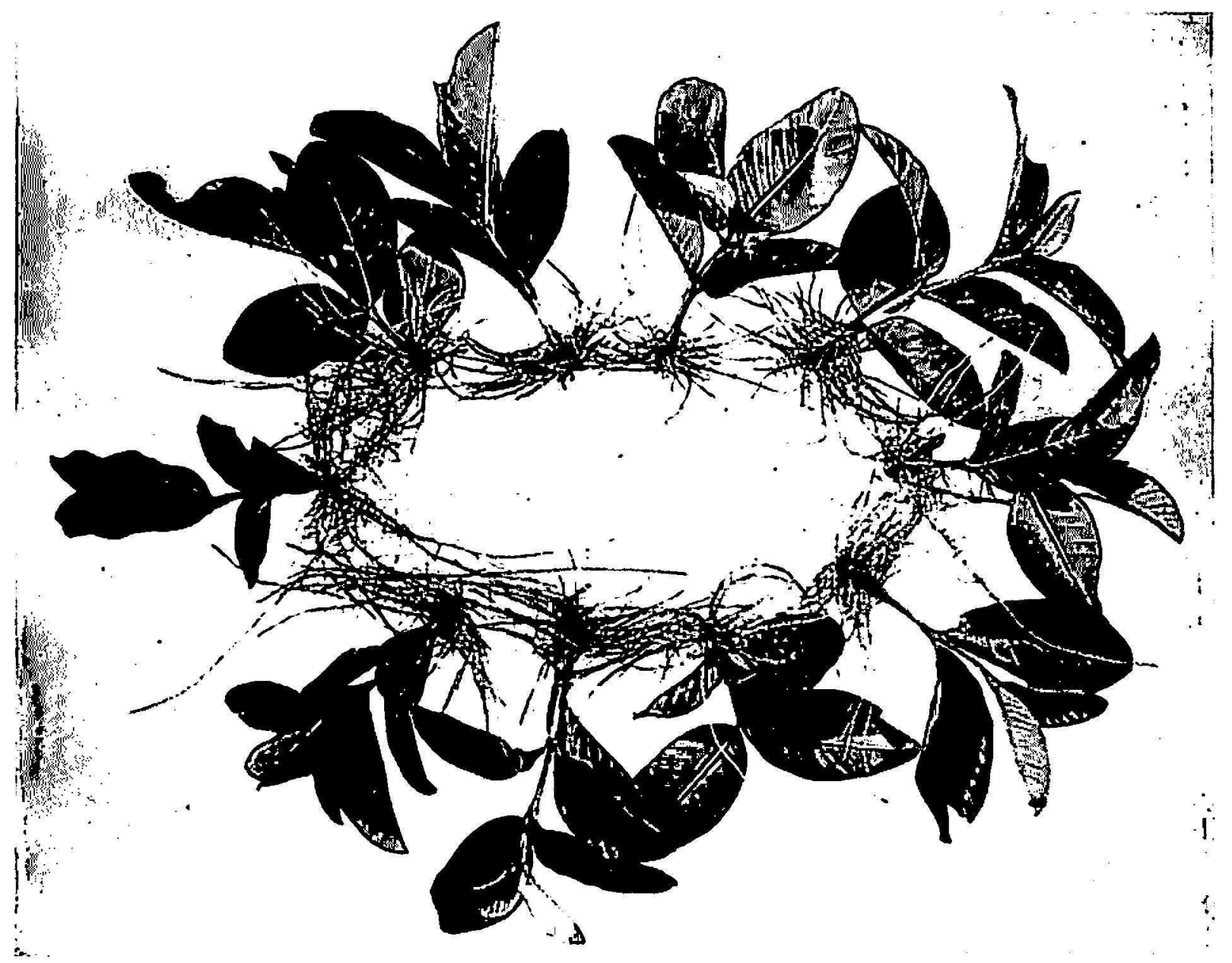

Fic. 3.-Rooted guava cuttings removed from the propagator 4 weeks after planting. These cuttings were treated with 200 p.p.m. of I.B.A.

In most of our earlier work severe infection with this fungus occurred, resulting in the very low incidence of rooting already mentioned, 20 percent or less. Usually the cuttings appeared to be free of the disease when planted, though latent infections were doubtless present. $A$ few leaf lesions and some blackened terminal buds usually became apparent during the first 2 weeks after setting out the cuttings. During the third and fourth weeks blackening of the terminal buds and blackening and abscission of the mature leaves spread rapidly. Some of the leaves remained attached long enough 
for the lesions to extend through the petiole and into the bark of the young stems. There the lesions continued to grow and rapidly killed the cuttings.

Cuttings which were killed by the disease usually did not have any roots, but some did have a few. In fact, a few of the apparently healthy cuttings succumbed to the disease after they had been transplanted into individual containers.

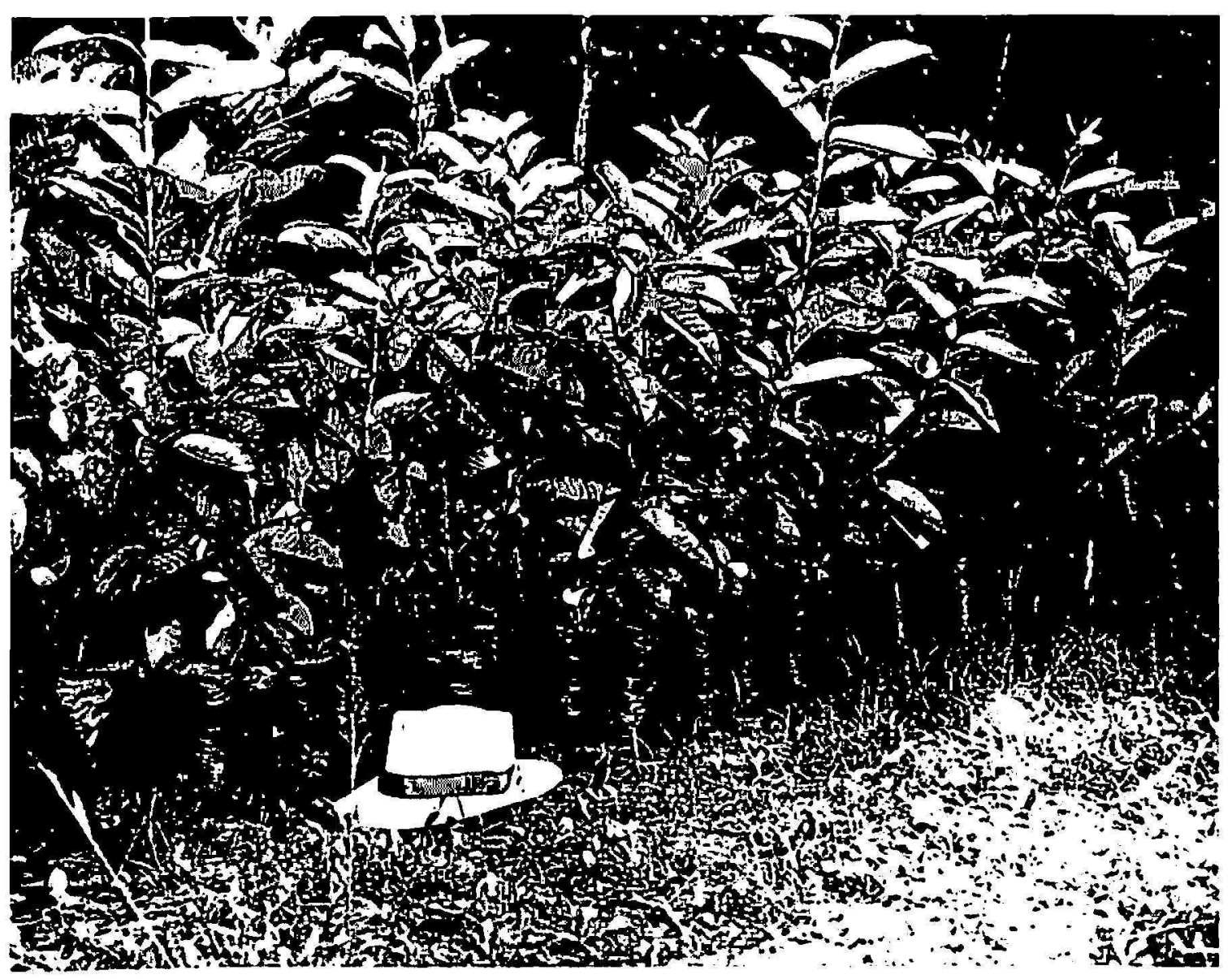

Fic. 4.-Guava plants derived from rooted cuttings ready to be set out in the field. The recommended propagating method makes it possible to produce from 500 to 1,000 such plants from a single 3 -year-old tree within 10 months. These plants are 8 montlis old, figured from the time cuttings were taken.

In recent rooting experiments we have noted early invasion of the underground parts of the cuttings. In one instance, in which tale mixtures of I.B.A. were used, it was quite apparent that such injury generally started at the eut surfaces where the lower leaves had been removed. In another, in which solutions were used, it appeared that the solutions without a fungicidal additive may themselves spread contamination. We therefore recommend that no leaves be removed. Because of possible spread of disease, and for the time being, we are not using sugar, or solutions at all, but are 
dusting the ends of the cuttings with strong mixtures of I.B.A. in talc. At present we are using 1 part of I.B.A. in 200 parts of talc prepared by the method of Stoutemeyer (4).

In the experiment described and discussed above the low incidence of disease doubtless resulted from the precautions suggested by our studies of this disease, which are being continued and which will be the subject of a projected subsequent publication. These precautions include the following: 1 , The use of cuttings from parent trees growing in a dry area; 2 , meticulous sanitation and the use of fresh or freshly sterilized rooting media; 3 , setting out the cuttings at wide spacing in the rooting bed so that contact between the leaves of adjacent cuttings is negligible.

\section{HANDLING AFTER ROOTING}

When the cuttings have rooted they are dug up and transplanted into individual containers filled with a sandy, rapid-draining potting mixture. The use of peat pots with a hole punched in the bottom can be very helpful, particularly when the early incidence of disease threatens to destroy the cuttings unless they are quickly separated. Cuttings with few, short roots, and even with no roots at all, can be transplanted into these small pots which are then placed in a tray and kept under mist for 1 to 2 weeks. Thereafter they are removed to a shady area where they are hand-watered for about a month. They can then be planted in the field or in larger containers, such as polyethylene bags.

Transplanting directly into black polyethylene bags measuring $4 \times 5 \times 12$ inches, or in gallon cans filled with light potting soil is the usual recommended procedure. Such containers are not placed under mist because of the danger of waterlogging. They are kept under shade, however, and the plants are syringed several times per day during the first 2 weeks. Thereafter they are hardened off and finally placed in full sunlight. These types of containers permit growing of the plants until they attain great vigor, and a height of $21 / 2$ to 3 feet. ligure 4 shows such plants ready to be set out in the field. Well-rooted cuttings that are free of disease can be thus handled with negligible or no losses whatever.

This propagating method enables one to produce from 500 to 1,000 large, healthy, homogeneous plants from a single 2- to 3-year-old parent tree within 10 months time. Such plants will bear some fruit in about a year after setting out. The parent plant also survives the treatment and can again be used as a source of material after a rest of 8 to 12 months. We find the method involves less work, produces a great many more plants from a single parent tree, and the resulting trees have much faster initial growth than plants propagated by air-layering. 


\section{SUMMARY}

1. A highly successful propagation method is described by which hundreds of side-sprouts are first induced on the parent guava tree. These are later cut and rooted under alternating mist, with leaves attached. By using this method it is possible to produce from 500 to 1,000 guava plants from a single 3-year-old tree within 10 months.

2. An experiment is also described and discussed which showed that different rooting media, such as coarse sand and very fine gravel, with Coco-peat, fir bark, Vermiculite, Perlite, and Mexifern, had no appreciable effect on rooting. But treatment with a relatively high concentration, 200 p.p.m., of indolebutyric acid improved and accelerated rooting markedly. Rooting was still further improved if 2 percent of sugar was combined with the indolebutyric acid treatment.

3. The high susceptibility of cuttings under mist to anthracnose disease is mentioned and the usual course of the disease described. Recommendations are suggested for reducing the incidence of this disease.

\section{RESUMEN}

1. Se describe un método muy eficaz de propagar la guayaba para lo cual, primero se provoca la formación de centenares de retoños en las plantas madres y luego éstos se recortan y se arraigan bajo riego atomizado y con las hojas adheridas.

2. Se describe y discute un experimento que demuestra muy palpablemente que 5 materiales de distintas características físicas usados como medio sustentador al arraigar los esquejes no ejercieron efecto alguno. En cambio, el tratamiento de los esquejes con ácido indolebutírico en concentraciones relativamente altas (200 p.p.m.) aceleró el arraigamiento y aumentó marcadamente el número de esquejes que formaron rá́ces. Cuando se combinó el uso de azúcar en solución al 2 por ciento con el ácido indolebutírico se mejoraron estos resultados aún más.

3. Se menciona la alta susceptibilidad de esquejes bajo riego atomizado a la antracnosis causada por Glomerella cingulata y se sugiere como evitar en gran parte los posibles daños causados por esta enfermedad.

\section{LITERATURE CITED}

1. Ruehle, Geo. D., A rapid method of propagation the guava Proc. Fla. State. Hort. Soc. 61 256-60, 1948.

2. Dedolph, R. R., and Bowers, A. L., Studies on guava propagation, Hawaii Farm Sci. 9 (2) 4-5, Oct. 1960.

3. Dávila, G., Propagación Asexual de Guayabas, Annual Report to the Director, Agr. Exp. Sta., Rio Piedras, P.R. 1948.

4. Jolicoeur, J. A., The rooting of guava, Proc. Caribbean Region, Amer. Soc. Hort. Sci. 6 pp. 57-9, 1962.

5. St jutemeyer, V. I., Talc as a carrier of substances inducing root formation in soft wood cuttings, Proc. Amer. Soc. Hort. Sci. 36 817-22, 1938. 